\title{
STUDY OF MACRO MECHANICAL PROPERTIES OF ULTRA HIGH STRENGTH CONCRETE USING QUARTZ SAND AND SILICA FUME
}

\author{
T.Chandra Sekhara Reddy ${ }^{1}$, J.K.Elumalai ${ }^{2}$ \\ ${ }^{I}$ Professor of Civil Engineering Department, G.Pulla Reddy Engineering College(Autonomous), Kurnool, A.P, India \\ ${ }^{2}$ PG Student, G.Pulla Reddy Engineering College (Autonomous), Kurnool, A.P, India
}

\begin{abstract}
Concrete is one of the necessary elements for structural work in the modern construction. In the decade, buildings around the world have become higher and so the structural strength demand for concrete is increased, they require high strength concrete. Ultra high strength concrete (UHSC) has been developed in the recent revolution of concrete. The major difference between ultra high strength concrete and conventional concrete is that no coarse aggregate is involved in ultra high strength concrete, but quartz sand, quartz powder are used instead, with high dosage of silica fume. In this present work, an attempt is made to develop ultra high strength concrete using locally available materials, to achieve a target compressive strength more than 180 Mpa. Heat treatment is well known method which can improve the micro structural properties, pozzalanic reactivity of silica fume, quartz powder and also mechanical properties and durability. The curing cycles employed are water curing and hot air curing. The cube specimens of size $70.6 \mathrm{~mm} \mathrm{X} 70.6 \mathrm{~mm}$ X $70.6 \mathrm{~mm}$ and cylindrical specimens of size 100mm dia X 200mm high were cast and exposed to a temperature of $200^{\circ} \mathrm{c}$ for duration of 24,48 and 72 hours at the age of $3^{\text {rd }}$ day followed with water curing till the age of 28 day testing. The results showed marked difference in compressive strength ranging from 187 Mpa to 142 Mpa. The samples cured under normal water only produced strength of $116 \mathrm{Mpa}$ with the mix considered. It is observed from the study that quartz powder, quartz sand, duration of temperature affects the compressive strength; hot air temperature curing increased the compressive strength up to $40 \%$ nearly when compared with the specimen under normal water curing only.
\end{abstract}

Keywords: Ultra high strength concrete, Silica fume, Quartz power, Quartz sand, Compressive strength, hot air curing.

\section{INTRODUCTION}

Ultra high strength concrete (UHSC) is a high strength concrete, formed from a special combination of constituent materials, which includes cement (ordinary Portland cement), silica fume, Quartz powder $(45 \mu \mathrm{m})$, Quartz sand $(0.15 \mathrm{~mm}$ to $1 \mathrm{~mm})$, High range water reducer and high tensile steel fibers.UHSC also called Ductile concrete due to it has a High capacity to take a load, deform and even support a flexural tensile load after initial cracking

Firstly UHSC was developed in the 1990s by Pierre Richard and Marcel Cheyrezy [1] at Bouygues laboratory in France. The sherbrooke bridge was the first UHSC structure which was constructed in Canada. UHSC has advanced mechanical physical properties with highly ductile cementious composites. Microstructure of the UHSC is optimized by precise grading of all particles which yield maximum density in the mix largely. UHSC uses the pozzalanic properties of highly refined silica fume and high strength hydrates are produced due to the phenomenon of optimization of Portland cement chemistry. Heat treatment has been applied to get excellent mechanical and durability properties.

The most important property of UHSC is self healing potentiality. Talking into sustainability point of view UHSC has cement more than three times of ordinary concrete thus it requires more energy and produce more $\mathrm{CO}_{2}$ but it has exceptional durability properties so that supposing lower maintenance cost for through life time of the structure, demolished material can be used as high quality recycled aggregate for new concrete.

UHSC will be suitable for pre-stressed application and for structure acquiring light and their components such as roofs, stadiums, longer span bridges, space structure, high pressure pipes, blast resistance structure and containment of nuclear wastes [3]. The work on UHSC in India started from last few years at SERC, Chennai the development of UHPC started with and without fibers and studied the effect of various heats curing regime on strength properties. (Harish K.V et al) [2]. Dili A.S. and Manu Santhanam [3] have studied mix design, mechanical properties and durability aspect of RPC. Prabhat ranjain prem et al. [4] studied influence of curing regimes on compressive strength of ultra high strength concrete, and suggested that $48 \mathrm{hrs}$ thermal curing followed by water curing strength gains the more than $200 \mathrm{Mpa}$. Reda.M..M et al.[5] reported that UHPC mixes having both silica fume and silica flour possessed dense and uniform microstructure which was observed using SEM micrographs. No significant of portlandite $(\mathrm{CH})$ was detected by XRD. The thermal curing converted weak $\mathrm{CH}$ to strong C-S-H gel during hydration, Different phases of crystallized $\mathrm{C}-\mathrm{S}-\mathrm{H}$ were observed. Very strong and moderately Xonolite $(\mathrm{C} 6 \mathrm{~S} 6 \mathrm{H})$ was a major product in 
mixtures. Harish K.V et al [6] studied the choice of ingredients and curing regimes plays prominent role in high strength concrete and in high performance concrete. Samples were casted using locally available ingredients. Achieved compressive strength of 170 Mpa under a combination of normal water curing, hot water curing and hot air curing. Dattatreya. J.K., et al. [7] studied several particle packing models to develop a mix proportion for the reactive powder concrete. The granular packing of materials like silica fume ,quartz powder, standard sand with cement were optimized and experimental results were compared with the theoretical packing models. K.M.Nag, et al. [8] investigated the mechanical properties and effect of thermal curing on RPC by comparisons with HPC.It was found that compressive strength. Split tensile strength and static modulus of elasticity are higher than HPC over the entire curing period for the same water to binder ratio.Chi-ming tam and Vivian Wing-yan Tam [9] conducted heat treatment with different temperatures on RPC and found that increasing temperature required a long duration. Chan yw and chu sh [10] reported that incorporation of silica fume in RPC matrix remarkably enhances the steel fiber matrix bond characteristics due to interfacial toughening effect upon fiber slip. Halit yazici et al. [11] developed an UHPC by combining silica fume, pulverized fly and pulverized granulated blast furnace slag with the Portland cement, Basalt and quartz powder were used as an aggregate in the mixtures, three different curing methods (standard, autoclave and stream curing) were applied to the specimens. Compressive strength of these mixtures is over $170 \mathrm{MPa}$

So the basic objective of the current investigation is to experience the production of UHSC. The key issues of the study are: to develop UHSC of compressive strength more than $180 \mathrm{Mpa}$,UHSC samples to be taken with change in quantity of quartz powder to study the influence of quartz powder on the compressive of UHSC with combination of normal water curing and thermal curing regimes.

\section{MATERIALS AND PROPERTIES}

\subsection{Cement}

The ultra tech 53 grade ordinary Portland cement which conforms to IS $12269-1987$, is used in the present study

\subsection{Silica Fume}

The Silica - Astrra chemicals Ltd-Chennai which conform to ASTM C 1240 and IS 15388:2003.It is in white powder form premium micro silica which contains latently reactive silicon dioxide and no chloride or other potentially corrosive substances. The physical and chemical properties are mentioned in Table 1
Table 1 physical and chemical properties of silica fume

\begin{tabular}{|l|l|l|}
\hline S1. No. & Properties & \\
\hline 1 & Form & Ultra fine amorphous powder \\
\hline 2 & Colour & white \\
\hline 3 & Specific gravity & 2.63 \\
\hline 4 & Pack Density & $0.76 \mathrm{gm} / \mathrm{cm}^{3}$ \\
\hline 5 & Specific surface & $20 \mathrm{~m}^{2} / \mathrm{g}$ \\
\hline 6 & Particle size & $15 \mu \mathrm{m}$ \\
\hline 7 & Sio $_{2}$ & $99.89 \%$ \\
\hline
\end{tabular}

\subsection{Quartz Powder}

The crushed quartz powder used in the experiments is in a form of white powdered quartz flour, which replaces fine aggregate from the conventional concrete. The quartz flour is also supplied by sriya sai refractory brick and minerals, dinnedevarapadu, Kurnool. The particle size used ranges from 10 to $45 \mu \mathrm{m}$. The specific gravity of quartz powder is 2.6

\subsection{Quartz Sand}

The quartz sand (QS) is supplied by Sathaya Narayana Minerals, Kodumoor, and Kurnool. It is in a form of yellowish-white high purity silica sand. The quartz sand used for the experimental studies are Grade $1(300 \mu \mathrm{m}$ $<\mathrm{G} 1>150 \mu \mathrm{m})$, Grade $2(600 \mu \mathrm{m}<\mathrm{G} 2>300 \mu \mathrm{m})$ and Grade 3 $(1180 \mu \mathrm{m}<\mathrm{G} 3>600 \mu \mathrm{m})$ and the specific gravity of quartz sand is 2.62

\subsection{Steel Fibers}

Hook end steel fibers having an aspect ratio of 67 was chosen with length of $30 \mathrm{~mm}$, diameter of $0.45 \mathrm{~mm}$, and tensile strength of $1500 \mathrm{Mpa}$ and procured from Dura flex steel fiber reinforcement redefined proceeded by kasturi composite pvt Ltd, Amravati Maharashtra India.

\subsection{Superplasticizer}

In order to increase the strength and also reduce the porosity (impermeability), i.e. to extend the durability and thus the life time of a concrete structure it is of utmost importance to keep the w/c as low as possible using superplasticizer (SP).In this study, Master Glenium ${ }^{\circledR}$ sky 8233formely B233 which is poly-carboxylic ether based hyper super plasticizer procured from BASF India Ltd construction chemicals-Secundarabad. It is an extremely high range water reducing agent which meets the requirement of IS 9103-1999 the properties of super plasticizer are given in Table 2 
Table 2 Properties of super plasticizer

\begin{tabular}{|l|l|l|}
\hline S.no & Properties & Glenium B-233 \\
\hline 1 & Type of SP & polycarboxylic ether \\
\hline 2 & Appearance & Light brown \\
\hline 3 & PH value & $\geq 6$ \\
\hline 4 & $\begin{array}{l}\text { Specific } \\
\text { gravity }\end{array}$ & 1.08 \\
\hline 5 & Solid content & Not less than $30 \%$ by weight \\
\hline 6 & $\begin{array}{l}\text { Recommended } \\
\text { dosage }\end{array}$ & $\begin{array}{l}500 \mathrm{ml} \text { to } 1500 \mathrm{ml} \text { for } 100 \text { of } \\
\text { cementious materials }\end{array}$ \\
\hline 7 & $\begin{array}{l}\text { Chloride } \\
\text { content }\end{array}$ & $<0.2 \%$ \\
\hline
\end{tabular}

\section{EXPERIMENTAL PROGRAME}

\subsection{Mix Proportioning}

Original mix design was arrived from the available literature and performing our own trails at laboratory and identified that Silica fume/Cement ratio and Quartz powder/Cement ratio 0.25 and 0.4 respectively were yield good mechanical properties. The optimal dosage of Steel fibre ratio is $2 \%$ by volume or about $156 \mathrm{~kg} / \mathrm{m}^{3}$. Details mix proportions of UHSC are mentioned in table 3. UHSC mix proportions to be taken with change in quantity of quartz powder.

\subsection{Mixing Procedure}

The mixing procedure adopted for mixing UHSC is followed by based on literature research.

- A pan mixer machine (40 kg capacity) was used to mix the UHSC.

- Premix (dry ingredients) was placed in mixer pan, and mixed for about 3 minutes while the mixer was rotating at a slow speed. Water (with $1 / 2$ of SP) was added to premix slowly over the course of 2 minutes.

- After 1 minute, the remaining SP was added to premix and mixing was continued at slow speed for two or three minutes.

- Additional mixing was performed at this speed until a uniform mixture was achieved and the mixture was transformed to a flowable selfcompacting consistency. The total mixing time for the various mixtures ranged from 20 to 25 minutes.

- Finally steel fibers were added to the mix slowly, when flowable consistency was achieved. After the fibers were added, mixing was continued for 2 minute to ensure that the fibers were well dispersed.

Table 3 Proportioning of UHSC mixes

\begin{tabular}{|l|l|l|l|l|}
\hline Mix & $\begin{array}{l}\text { QS-1 } \\
30 \% \\
\text { QP }\end{array}$ & $\begin{array}{l}\text { QS-2 } \\
35 \%\end{array}$ & $\begin{array}{l}\text { QS-3 } \\
40 \% \\
\text { QP }\end{array}$ & $\begin{array}{l}\text { QS-4 } \\
45 \% \\
\text { QP }\end{array}$ \\
\hline Material & $\mathrm{Kg} / \mathrm{m}^{3}$ & $\mathrm{Kg} / \mathrm{m}^{3}$ & $\mathrm{Kg} / \mathrm{m}^{3}$ & $\mathrm{Kg} / \mathrm{m}^{3}$ \\
\hline Cement & 750 & 750 & 750 & 750 \\
\hline Silica Fume & 187.5 & 187.5 & 187.5 & 187.5 \\
\hline
\end{tabular}

\begin{tabular}{|l|l|l|l|l|} 
Quartz Powder & 225 & 262.5 & 300 & 337.5 \\
\hline Quartz Sand & 1007.82 & 970.1 & 932.4 & 894.69 \\
\hline Steel Fiber & 156.2 & 156.2 & 156.2 & 156.2 \\
\hline $\begin{array}{l}\text { Super } \\
\text { Plasticizer }\end{array}$ & 11.25 & 11.25 & 11.25 & 11.25 \\
\hline Water & 187.5 & 187.5 & 187.5 & 187.5 \\
\hline W/B Ratio & 0.2 & 0.2 & 0.2 & 0.2 \\
\hline
\end{tabular}

\subsection{Specimen Preparation and Curing}

For each mix of concrete, 4 sets of samples were cast, each set contain 3 cubes $(70.6 \mathrm{mmX} 70.6 \mathrm{mmX} 70.6 \mathrm{~mm})$ and 3 cylinders of size (100 mm dia. X $200 \mathrm{~mm}$ high), demoulded after 24 hours then they were allowed for normal water curing for one day. At the age of third day 3 sets samples were exposed to hot air oven curing at temperature of $200^{\circ} \mathrm{C}$. One set of samples were taken from the oven when they had cured for 24 hours, after which they were allowed to attain thermal equilibrium with atmospheric temperature and then kept in water till the date of testing. Similarly second set and third set samples were taken out from the oven when they had thermally cured for 48 hours and 72 hours respectively, after which they allowed to attain thermal equilibrium and then kept in water till the age of 28 days. One set of samples completely cured in normal water.

\subsection{Testing}

Three cube specimens and two cylinders were cast and tested for each batch of UHSC to compute compressive strength and split tensile strength at 28 days respectively. Two tests were carried out using compression testing machine of capacity $2000 \mathrm{KN}$. The modulus of elasticity is a function of the compressive strength, as per ACI 363R-92.99 gives the modulus of elasticity (in GPa) is approximately related to the compressive strength (in $\mathrm{MPa}$ ) by the following expression

Theoretical Modulus of Elasticity $=3.65 \sqrt{f_{c}}$

$f_{c}=$ compressive strength in Mpa

\section{RESULTS AND DISCUSSION}

Arriving a optimal composition with locally available materials is important to achieve compressive strength more than 180 Mpa. Hence the effect of several parameters on compressive strength were investigated which comprise of percentages of quartz powder and duration of temperature and curing regimes. During the mixing it was observed that the mixes appeared to be very sensitive to any variation of the quartz powder, sand to be added to the mixes. Till a date there is no standard guidelines for mix design of UHSC, literature was referred to the design mixes.

\subsection{Density of UHSC Specimens}

The density of all specimens is varied between $23.44-26.06$ $\mathrm{KN} / \mathrm{m}^{3}$ 


\subsection{Effect of Quartz Powder on Compressive}

\section{Strength of UHSC}

Hydrated cement alone can't help to evaluate the compressive strength of UHSC but other parameters contribute marginally such as quartz powder and curing regimes. Here quartz powder act as effective filler material at normal water curing and also it's act as a pozzalanic material at higher temperature. From the observations of Fig-1 the addition of quartz powder produce the better results under the hot air oven curing than that of normal water curing. The results show that maximum compressive strength of $187 \mathrm{Mpa}$ is attained at quartz powder of $40 \%$ content samples with thermally cured for one day. This is possible due to increased proportion of fine fillers that enhance the packing density, pore fill in action and long chains of C-H-S gel. Split tensile strength is also maximum for $40 \%$ quartz powder content samples with thermally cured for three days so split tensile strength is irrespective of the compressive strength for all mixes

Table 4 Compressive strength of UHSC mixtures in MPa

\begin{tabular}{|l|l|l|l|l|}
\hline Mix & QS-1 & QS-2 & QS-3 & QS-4 \\
\hline $\begin{array}{l}\text { Percentage of quartz } \\
\text { powder by weight of } \\
\text { cement }\end{array}$ & 30 & 35 & 40 & 45 \\
\hline Normal Water Curing & 110 & 104 & 116 & 108 \\
\hline $\begin{array}{l}\text { One Day Thermal } \\
\text { Curing }\end{array}$ & 172 & 162 & 187 & 170 \\
\hline $\begin{array}{l}\text { Second Days Thermal } \\
\text { Curing }\end{array}$ & 168 & 142 & 170 & 173 \\
\hline $\begin{array}{l}\text { Three Days Thermal } \\
\text { Curing }\end{array}$ & 171 & 160 & 179 & 168 \\
\hline
\end{tabular}

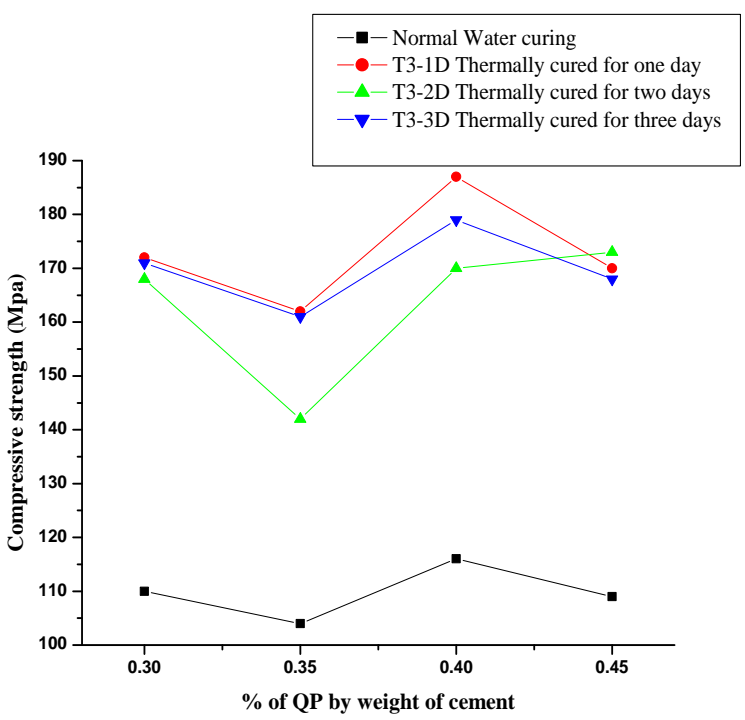

Fig.1 The variation of compressive strength versus $\%$ quartz powder by weight of cement

\subsection{Effect of Thermal duration on Compressive Strength of UHSC}

The compressive strength results with varying quartz powder and different curing regime are presented in table4.The variation of compressive strength versus curing regimes is presented in Fig-2. From the Fig.2, one day thermal curing regime is optimal and gives good compressive strength results for the same mixes than that of two days hot air oven curing and three days hot air oven curing, a temperature of $200^{\circ} \mathrm{C}$ was maintained.. Hence it is suggested that one day hot air oven curing is effective and economical

The hot air cured samples shown gradually rise in compressive strength at one day and decrease at second day and quite increase at third day, so longer heating duration of samples effects the compressive strength of concrete is not much for this the possible reason could be high early age autogenous shrinkage as well as rapid surface drying and surface cracking because of its low water binder ratio and addition of high fineness admixture

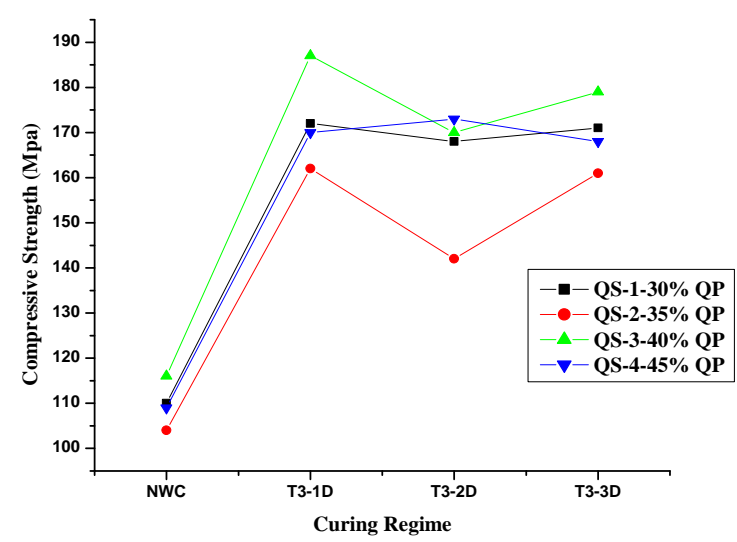

Fig.2The variation of compressive strength versus curing regime

\subsection{Influence of curing Regime}

An adequate supply of moisture is essential to ensure that hydration is sufficient to reduce the porosity to a level such that the desired strength can be attained. The combined effect of normal water curing and thermal curing at various ages on compressive strength is shown in Fig. 2.Thermal regime has an importance which activates the pozzalanic reaction of silica fume and quartz powder otherwise they will act as filler not as binder materials.

Thermal curing regime enhances the micro structural changes of hydrated structure. Increasing temperature and duration causing formation of different C-S-H gel crystal such as Tobermorite, xonotlite and scwatite these micro structural changes are investigated by SEM and XRD analysis. From the Fig. 1 it is observed that thermal curing regime increase the compressive strength up to $40 \%$ nearly when sample compared of normal water curing. 
The split tensile strength results with varying quartz powder and different curing regime are presented in table- 5 . The variation of split tensile strength versus curing regime is presented in Fig-3..From the Fig-3, it was observed that there was increase in split tensile strength of $24 \%$ for hot air oven cured specimens when compared normal water cured specimens, it was noticed that QS-3 at three days hot air oven cured specimens had higher split tensile strength than that of other mix proportions and Split tensile strength increased with increasing compressive strength at one day hot air oven cured specimens, there is quite decrease in Split tensile strength of two days hot air oven cured specimens and again slightly increase at three days hot air oven cured specimens.

Table 5 Split Tensile strength of UHSC mixtures in $\mathrm{MPa}$

\begin{tabular}{|l|l|l|l|l|}
\hline Mix & QS-1 & QS-2 & QS-3 & QS-4 \\
\hline $\begin{array}{l}\text { Percentage of quartz } \\
\text { powder by weight of } \\
\text { cement }\end{array}$ & 30 & 35 & 40 & 45 \\
\hline Normal Water Curing & 13 & 9 & 13 & 11 \\
\hline $\begin{array}{l}\text { One Day Thermal } \\
\text { Curing }\end{array}$ & 14 & 13 & 16 & 15 \\
\hline $\begin{array}{l}\text { Second Day Thermal } \\
\text { Curing }\end{array}$ & 15 & 13 & 14 & 12 \\
\hline $\begin{array}{l}\text { Third Day Thermal } \\
\text { Curing }\end{array}$ & 10 & 14 & 17 & 14 \\
\hline
\end{tabular}

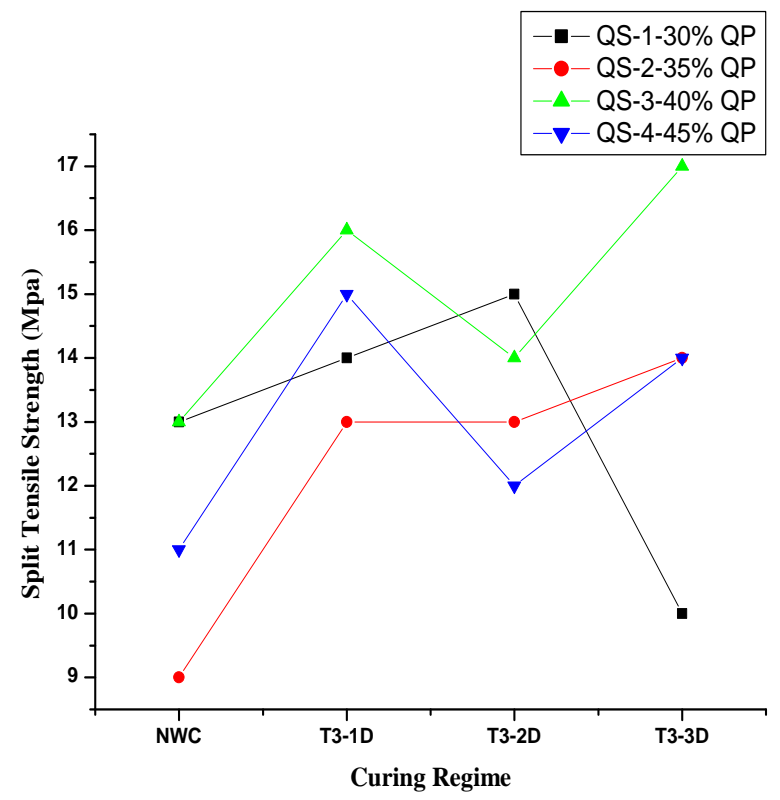

Fig.3 The variation of split tensile strength versus curing regime

The theoretical Modulus of Elasticity results with varying quartz powder and different curing regime are presented in table-6.The variation of theoretical Modulus of Elasticity versus curing regime is presented in Fig-4.From the Fig.4, one day thermal curing regime is optimal and gives good theoretical Modulus of Elasticity results for the same mix than that of two days hot air curing and three days hot air oven curing, a temperature of $200^{\circ} \mathrm{C}$ was maintained and it was observed that there was increase in theoretical Modulus of Elasticity for hot air oven cured specimens when compared normal water cured specimens

Table 6 Theoretical Modulus of Elasticity of UHSC mixtures in GPa

\begin{tabular}{|l|l|l|l|l|}
\hline Mix & QS-1 & QS-2 & QS-3 & QS-4 \\
\hline $\begin{array}{l}\text { Percentage of quartz } \\
\text { powder by weight of } \\
\text { cement }\end{array}$ & 30 & 35 & 40 & 45 \\
\hline Normal Water Curing & 38 & 37 & 39 & 38 \\
\hline $\begin{array}{l}\text { One Day Thermal } \\
\text { Curing }\end{array}$ & 48 & 46 & 50 & 48 \\
\hline $\begin{array}{l}\text { Second Day Thermal } \\
\text { Curing }\end{array}$ & 47 & 44 & 48 & 48 \\
\hline $\begin{array}{l}\text { Third Day Thermal } \\
\text { Curing }\end{array}$ & 48 & 46 & 49 & 47 \\
\hline
\end{tabular}

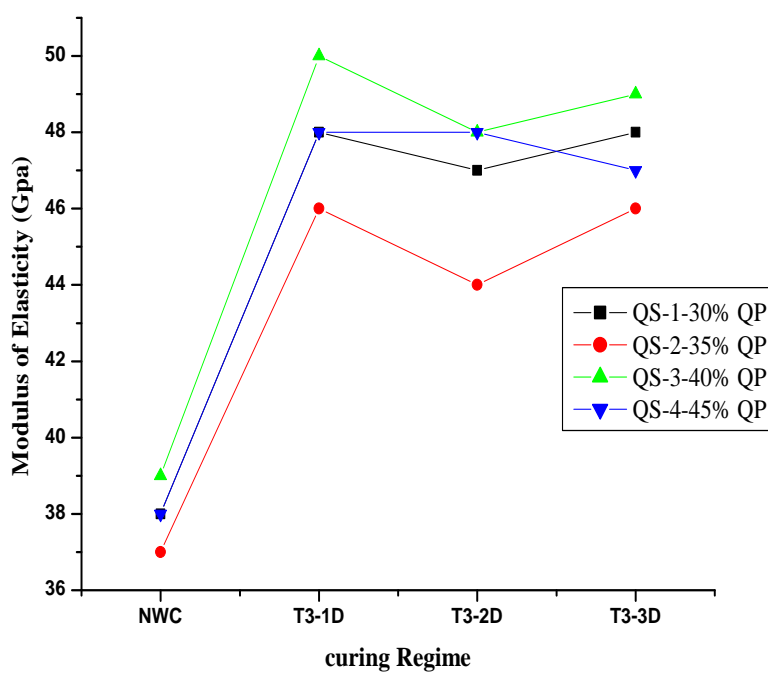

Fig 4 The variation of theoretical Modulus of Elasticity versus curing regime

\subsection{CONCLUSIONS}

From the present study the following conclusions can be drawn

- The maximum compressive strength of $187 \mathrm{Mpa}$ obtained for mix with $40 \%$ quartz powder and $24 \mathrm{hr}$ thermal curing

- The maximum split tensile strength of $17 \mathrm{Mpa}$ obtained for mix with $40 \%$ quartz powder and $72 \mathrm{hr}$ thermal curing

- The maximum Modulus of Elasticity of 50GPa obtained for mix with $40 \%$ quartz powder and $24 \mathrm{hr}$ thermal curing

- Maximum compressive strength, split tensile strength and Modulus of Elasticity attained at quartz powder of $40 \%$ by weight of cement 
- It is observed that thermal curing regime increase the compressive strength up to $40 \%$ nearly when samples compared of normal water curing

- One day thermal curing regime is sufficient and economical which improves the compressive strength significantly than other two days thermal curing and three days curing regime.

- At normal water curing, pozzalanic reaction of silica fume and quartz powder is not activated,only they act as filler material

- Thermal curing regime activates the pozzalanic reaction of silica fume, quartz powder and micro structural changes of the hydrated structure.

\section{REFERENCES}

[1] Pierre Richard, Marcel Cheyrezy, "Composition of Reactive Powder Concrete", Cement and Concrete Research Journal, 25(7), pp 1501-1511. 1995

[2] Harish K V, Dattatreya J K and Neelamegam M "Effect of fiber addition, heat treatment, and preset pressure on mechanical properties of ultra-highstrength mortars". 2011 Transportation Res. Rec. J. Transp.Res. Board 2240: 59-69

[3] Dili A. S. and Manu Santhanam. "Investigation on Reactive Powder Concrete: A Developing Ultra High-Strength Technology" Indian Concrete Journal, April-2004, pp.33-38

[4] Prabhat ranjain prem, B.H Bharatkumar and Nagesh iyer "Influence of curing regimes on compressive strength of concrete", Sadhana vol.38, Part 6, dec 2013, pp 1421-1431.

[5] Reda.M.M, Shrivea G N and Gillotta E J "Microstructural investigation of innovative UHPC". Cem.Concr. Res. 29(3): 323-329 1999

[6] Harish K V, D.Sabitha,Dattatreya J K and Neelamegam M ., "Role of ingredients and of curing regime in ultra high strength powder concretes", Journal of Structural Engineering, Vol. 34, No. 6, pp. 421-428, 2008

[7] Dattatreya, J.K., Harish, K.V., and Neelamegam, M., (2007), "Use of Particle Packing Theory for the Development of Reactive Powder Concrete", The Indian Concrete Journal, September 2007, pp 31-45.

[8] K. M. Nag, C. M. Tam and V. W. Y. Tam "Studying the production process and mechanical Properties of reactive powder concrete", Magazine of Concrete Research, 2010, 62, No. 9, September, 647-654.

[9] Chi-ming Tam, Vivian Wing-yan Tam "Micro structural behavior of RPC under different heating regimes" Magazine of concrete research vol 64 issue 3, 2012 .

[10] Chan yw, chu SH, "Effect of silica fume on steel fiber bond characteristic in reactive powder concrete", cement concr Res 2004; 34:1167-72

[11] Halit yazici "The effect of curing on compressive strength of ultra high strength concrete with high volume of mineral admixtures" Building and Environment 2007; 42-2083-2089
[12] Testing aggregates: "Methods of determination of density", BS: 812(Part 2), 1995, British Standards institute.

[13] S. Shaw, S.M. Clark, C.M.B. Henderson "Hydrothermal formation of the Calcium silica hydrates, Tobermorite, xonotlite:an insitu synchrotron study", Elsevier, chemical geology 167 (2000) 129-140.

[14] "Methods of test for strength of concrete", IS $516: 1959$,Bureau of Indian Standards, New Delhi,2002.

[15] Prabhat R P, Bharatkumar B H and Iyer N R "Mechanical properties of ultra high performance concrete". Proceedings of World Academy of Science, Engineering and Technology. No. 68. World Acad. Sci. Eng. Technol. 351(68): 1969 (2012)

[16] Stephen Brunauei "Tobermorite gel-the heart of concrete", Research and development laboratories of the port cement association, American scientist Vol. 50, No.1, 210-229 (March 1962).

[17] DIFFRACTION Saskia Bernstein "Determination of reaction kinetics and mechanism of $1.13 \mathrm{~nm}$ Tobermorite by insitu neutron diffraction". Thesis 2011. 